\title{
Wanprestasi Manajer Investasi Terhadap Investor Reksadana
}

\author{
Marselo Valentino Geovani Pariela \\ Dosen Fakultas Hukum Universitas Pattimura \\ E-mail :mpariela@gmail.com
}

\begin{abstract}
The Investment Manager is the party managing Mutual Funds either in the form of the Company or in the form of Collective Investment Contract, one of Mutual Fund products is Mutual Fund Shares. Investment Managers in managing Mutual Funds perform securities portfolio activities as well as collective investment portfolios. Portfolio is intended to minimize the risks that occur when managing the investment, with the portfolio, expected returns that expected investors can be reached maximally in the management of mutual funds Shares never escape the error. Such an Investment Manager's mistake may cause a loss on the part of the investor.
\end{abstract}

Keywords: default, mutual fund

\section{A. PENDAHULUAN.}

Melihat

perkembangan perekonomian di Indonesia saat ini, pasar modal merupakan alternatif terbaik dalam berinvestasi. Hal ini didukung oleh rendahnya bunga tabungan dan suku bunga penjaminan deposito yang relatif kurang menguntungkan, dibandingkan dengan perkembangan tingkat inflasi di Indonesia. Meningkatnya minat investor domestik dan asing di pasar modal Indonesia membuat makin maraknya perkembangan transaksi di pasar modal.

Untuk itu diperlukan informasi serta pembelajaran dari pemerintah dan institusi keuangan terkait yang berkaitan dengan kinerja pasar modal, serta resiko yang dihadapi. Selain itu juga dalam menghadapi ketidakpastian kinerja pasar modal, Manajer Investasi memegang peranan penting dalam pengelolaan dana yang dikumpulkan secara kolektif dari masyarakat. Kurangnya informasi mengenai perkembangan perekonomian di Indonesia bagi para investor merupakan suatu ganjalan untuk mendapatkan portofolio instrumen investasi yang tepat dan sesuai dengan tingkat resiko yang dapat diterima oleh para investor. Dimasa sekarang ini, dimana menyimpan dana pada tabungan konvensional dan deposito tidak lagi menguntungkan maka berinvestasi pada reksadana merupakan pilihan yang tepat. Hal ini disebabkan karena bunga pada tabungan dan deposito lebih kecil dari tingkat inflasi sehinga Time Value of Money bukanlah bertambah bila ditabung 
tetapi akan semakin berkurang. Oleh karena itu, berinvestasi pada reksadana menjadi alternatif yang menggiurkan karena imbal hasilnya lebih besar dari pada instrument keuangan konvensional lainnya. ${ }^{1}$ Berdasarkan data Badan Pengawas Pasar Modal (BAPEPAM), perkembangan reksadana sebagai salah satu instrument investasi di pasar modal Indonesia sangat signifikan. Hal tersebut terlihat dari jumlah perkembangan reksadana, jumlah investor, dan total Nilai Aktiva Bersih (NAB). Pada tahun 1996, yaitu saat reksadana didirikan pertama kali di Indonesia, jumlah reksadana tercatat 25 (dua puluh lima) reksadana yang terdiri dari 6 (enam) reksadana saham, 6 (enam) reksadana campuran, 1 (satu) reksadana pasar uang, dan 12 (dua belas) reksadana pendapatan tetap dengan total investor sebanyak 2.441 (dua ribu empat ratus empat puluh satu) investor dan total Nilai Aktiva Bersih (NAB) sebesar Rp. 2.782.310.000,- (dua millyar tujuh ratus delapan puluh dua juta tiga ratus sepuluh ribu rupiah). ${ }^{2}$

Reksadana campuran, 30 (tiga puluh) reksadana. Akan tetapi pada akhir tahun 2003 jumlah reksadana telah mencapai 186 (seratus delapan puluh enam) reksadana dengan perincian sebagai berikut : 20 (dua puluh) reksadana saham, 20 (dua puluh) reksadana campuran, 30 (tiga puluh) reksadana pasar uang, dan 116 (seratus enam belas) reksadana pendapatan tetap. Total investor yang berinvestasi pada reksadana pada akhir tahun 2003 tersebut berjumlah 171.712 (seratus tujuh puluh satu ribu tujuh ratus dua belas) investor dan total Nilai Aktiva Bersih (NAB) sebesar Rp. 69.477.720.000.- (enam puluh sembilan milliar empat ratus tujuh puluh tujuh juta tujuh ratus dua puluh ribu rupiah). Dari

\footnotetext{
1 www.nellafrnd.file.wordpress.com/ Diakses tanggal 23 Maret 2017

2 Ibid
}

pada saat itu hingga saat ini Nilai Aktiva Bersih (NAB) reksadana terus berkembang, pencapaian hingga awal 2008 Nilai Aktiva Bersih reksadana sudah mencapai Rp. 94.000.000.000.000,- (sembilan puluh empat triliun rupiah), nilai ini hampir mendekati total Nilai Aktiva Bersih (NAB) sebelum terjadinya krisis reksadana pada 2005 yang sebesar Rp. 104.000.000.000.000,- (seratus empat triliun rupiah). Perkembangan ini juga di iringi dengan berkembang pula Agen Penjual Reksadana (APERD) dengan telah terdaftarnya 25 (dua puluh lima) bank sebagai Agen Penjual Reksadana (APERD). ${ }^{3}$

Seiring dengan perkembangan tersebut maka banyak investor yang ingin menginvestasikan dananya di pasar modal, namun seringkali mereka tidak mempunyai cukup dana dan pengetahuan untuk dapat berinvestasi dan meraih keuntungan di pasar modal. Selain itu, melakukan investasi bukanlah hal yang mudah karena banyak hal yang harus diperhitungkan, antara lain adalah faktor resikonya. Seperti kita ketahui, reksadana selain memberikan imbal hasil yang cukup tinggi juga mempuyai sejumlah resiko yang bervariasi tergantung karakteristik reksadana itu sendiri.

Dengan semakin banyaknya reksadana di Indonesia maka investor memiliki lebih banyak pilihan sehingga investor harus lebih jeli dalam mempertimbangkan reksadana mana yang harus dipilih sesuai dengan tujuan investasinya. Dalam memilih reksadana yang sesuai bagi investor terdapat beberapa hal yang harus dipertimbangkan. Pertama, berapakah imbal hasil yang diberikan?, imbal hasil yang diperoleh oleh para investor reksadana berasal dari Dividen, tambahan Unit Penyertaan (UP) atau Capital Gain karena penjualan kembali Unit Penyertaan (UP) reksadana.

${ }^{3}$ Ibid 
Kedua, bagaimanakah keamanan dan tingkat resikonya berdasarkan Underlying Asset dari suatu produk reksadana tersebut. Ketiga, bagaimana kinerja atau profesionalisme Manajer Investasi reksadana tersebut. Berdasarkan beberapa pertimbangan diatas, investor tersebut harus dapat menilai kinerja reksadana yang ditujukan oleh imbal hasil yang sudah disesuaikan dengan tingkat resiko dari reksadana.

Sebagai salah satu jenis efek dalam berinvestasi, reksadana mempunyai ciri-ciri yang unik apabila dibandingkan dengan jenis-jenis investasi lainnya. Dalam reksadana para investor membeli penyertaan atas kumpulan-kumpulan efek yang dikelola oleh Manajer Investasi yang sudah ahli, dengan tujuan mendapatkan keuntungan. Dana investor digunakan oleh manager investasi untuk mengelola portofolio investasi efek, untuk memperoleh keuntungan yang kemudian hasil keuntungan tersebut didistribusikan kembali kepada investor. Akan tetapi, manager investasi yang diberi kewenangan untuk mengelola dana hanya dapat menginvestasikan kembali dana-dana tersebut dalam bentuk portofolio efek yang telah disepakati sebelumnya dan diizinkan oleh Badan Pengawas Pasar Modal dan Lembaga Keuangan (BAPEPAM - LK). Jadi, disini manager investasi adalah sebagai pengelola sekuritas, yaitu membeli dan menjual efek-efek yang diterbitkan perusahaan lain guna kepentingan investor. ${ }^{4}$ Kemudian manager investasi adalah pihak yang mengelola portofolio efek untuk para nasabah atau mengelola portofolio investasi kolektif untuk sekelompok nasabah, kecuali perusahaan asuransi, dana pensiun dan bank yang melakukan sendiri kegiatan usahanya berdasarkan

Peraturan

\footnotetext{
4 Munir Fuady, Pasar Modal Modern Cetakan ke-1, Bandung, Citra Aditya Bakti, 1996, hlm 106.
}

Perundang-Undangan yang berlaku. ${ }^{5}$

Peranan manager investasi sangat penting dalam mengelola reksadana di pasar modal dan merupakan perusahaan efek yang memberikan jasa pengelolaan portofolio efek nasabah dengan memperoleh imbalan dihitung berdasarkan perseroan tertentu dari nilai dana yang dikelolanya. ${ }^{6}$ Sesungguhnya peraturan mengenai tanggung jawab manager investasi telah diatur dalam Undang-Undang Nomor 8 Tahun 1995 tentang Pasar Modal Pasal 27 ayat (1), Manajer Investasi wajib dengan itikad baik dan penuh tanggung jawab menjalankan tugas sebaik mungkin semata - mata untuk kepentingan reksadana. Mengingat semua dana yang dikelola oleh manager investasi adalah dana masyarakat, perlu adanya pengamanan maksimal dengan mewajibkan manager investasi untuk melaksanakan tugasnya dengan sebaik mungkin untuk kepentingan reksadana. Dalam hal Manajer Investasi tidak melaksanakan kewajibannya, manager investasi tersebut wajib bertanggung jawab atas segala kerugian yang timbul karena tindakannya. Manajer Investasi berdasarkan ayat ini dibebani tanggung jawab atas kerugian reksadana yang timbul karena pengelolaan yang tidak dilakukan dengan itikad baik dan tidak dengan penuh tanggung jawab untuk kepentingan reksadana (penjelasan Pasal 27 ayat (2) Undang - Undang Nomor 8 Tahun 1995 tentang Pasar Modal ).

Mengingat dalam pengelolaan investasi reksadana dilakukan oleh manager investasi maka usaha jasa ini dapat digolongkan sebagai bisnis kepercayaan. Dengan demikian diperlukan adanya persyaratan kejujuran dan integritas moral yang tinggi dari pelakunya di dalam melaksanakan

\footnotetext{
5 Ibid

${ }^{6}$ Ibid
} 
amanat investor. Hilangnya kepercayaan investor berarti hilangnya peluang bisnis perusahaan reksadana bahkan lebih dari itu dapat merusak tatanan tujuan dan sistem pasar modal itu sendiri. Di sinilah dituntut profesionalisme manager investasi yang harus menimbulkan kepercayaan pemodal. Di dalam reksadana juga ada kemungkinan kemungkinan kerugian dikarenakan tidak diberikannya informasi mengenai perkembangan usaha reksadana. 7 Manager Investasi dari reksadana ini lalai memberi tahu perkembangan dana yang ditanamkan pada berbagai investasi reksadana. Akibatnya ketika terjadi keadaan yang merugikan investasi tersebut, investor tidak mengetahuinya, sehingga investor tidak melakukan tindakan yang dapat menyelamatkan investasinya, misalnya dengan menarik dananya dari reksadana. ${ }^{8}$

Akibatnya investor mengalami kerugian. Namun dalam hal ini investor tidak dapat meminta pertanggungjawaban hukum terhadap kelalaian yang dilakukan Manajer Investasi tersebut. Hal ini dikarenakan belum ada ketentuan hukum yang mengatur tentang sanksi bagi manager investasi yang lalai memberi informasi kepada investor, dengan kata lain investor berada dalam keadaan tidak terlindungi. Berdasarkan adanya kemungkinan terjadinya wanprestasi oleh reksadana tersebut, penulis tertarik untuk meneliti tentang : Kajian Hukum Tentang Tanggungjawab Manajer Investasi Terhadap Investor Reksadana Jika Terjadi Wanprestasi

\footnotetext{
7 Gunawan Widjaja dan Almira Prajna Ramaniya. Reksa Dana dan Peran Serta Tanggung Jawab Manajer Investasi dalam Pasar Modal. Seri Pengetahuan Pasar Modal. PrenadaMedia Group, Jakarta, 2006. hlm.4.

${ }^{8}$ Hadisoeprapto, Hartono, Pokok-Pokok Hukum Perikatan Dan Hukum Jaminan, Liberty, Yogyakarta, 1996, hlm. 53.
}

\section{B. PEMBAHASAN}

\section{Perbuatan Manajer Investasi yang dapat Merugikan Investor dalam Reksadana}

Manajer Investasi sebagai pengelola Reksadana mempunyai tugas untuk mengelola investasi pada Reksadana sehingga diharapkan memberikan keuntungan bagi para pemegang saham, dalam menjalankan tugasnya, BAPEPAM-LK telah mengeluarkan peraturan tentang perbuatan-perbuatan yang dilarang bagi Manajer Investasi. Hal ini untuk mencegah timbulnya risiko-risiko yang dapat merugikan investasi. $^{9}$

Selain perbuatan yang dilarang oleh BAPEPAM-LK tersebut, ada beberapa perbuatan Manajer Investasi yang dapat merugikan investasi. Salah satunya adalah pemberian informasi yang menyesatkan investor. Para investor, khususnya investor professional dan investor institusional selalu aktif mengumpulkan berbagai informasi dan memanfaatkannya untuk memahami harga-harga saham yang ditawarkan dalam pasar perdana maupun pasar sekunder. Informasi yang dikumpulkan adalah informasi yang mengandung fakta material. ${ }^{10}$

Pasal 1 butir 7 Undang-Undang Nomor 8 Tahun 1995 tentang Pasar Modal Informasi atau fakta material adalah informasi atau fakta penting dan relevan mengenai peristiwa, kejadian, atau fakta yang dapat mempengaruhi harga efek pada bursa efek dan atau keputusan pemodal, calon pemodal, atau pihak lain yang berkepentigan atas informasi atau fakta tersebut.

\footnotetext{
9 Bismar Nasution, Keterbukaan Dalam Pasar Modal. Fakultas Hukum Universitas Indonesia, Program Pascasarjana, Jakarta, 2001, hal. 65

${ }^{10}$ Ibid
} 
Selanjutnya Keputusan Ketua BAPEPAM Nomor : Kep 86/PM/1996 dan Peraturan Nomor X.K1, bahwa:

Informasi atau fakta yang diperkirakan dapat mempengaruhi efek atau keputusan investasi pemoodal, antara lain hal-hal sebagai berikut:

a. Penggabungan usaha, pembelian saham, peleburan usaha, atau pembentukan usaha patungan;

b. Pemecahan saham atau pembagian deviden saham;

c. Pendapatan dari deviden yyang luar biasa sifatnya;

d. Perolehan atau kehilangan kontrak penting;

e. Produk atau penemuan baru yang berarti;

f. Perubahan dalam pengendalian atau perubahan penting dalam manajemen;

g. Pengumuman pembelian kembali atau pembayaran efek yang bersifat utang;

h. Penjualan tambahan efek kepada masyarakat atau secara terbatas yang material jumlahnya;

i. Pembelian, atau kerugian penjualan aktiva yang material;

j. Perselisihan tenaga kerja yang relative penting;

k. Tuntutan hukum yang penting terhadap perusahaan, dan tau direktur atau komisaris perusahaan;

1. Pengajuan Tawaran untuk pembelian efek perusahaan lain;

m. Pengajuan tawaran untuk pembelian efek perusahaan lain;

n. Penggantian kuntan yang mengaudit perusahaan;

o. Penggantian wali amanat;

p. Perusahaan tahun fiskal perusahaan.

Selain pemberian fakta material yang menyesatkan yang dapat merugikan investor, kelalaian Manajer Investasi juga dapat merugikan investor. Disebut merugikan investor apabila kelalian tersebut dapat menurunkan Nilai Aktiva Bersih Saham investor, sehingga keuntungan yang diharapkan oleh investor menjadi hilang. Kelalaian Manajer Investasi tersebut dapat berupa kesalahan penghitungan NAB (Nilai Aktiva Bersih), atau juga dapat dimisalkan, ada dana tunai yang masuk ke Reksadana dan Manajer Investasi sedang rapat seharian dan lupa melakukan penempatan dana sehingga tingkat pengembalian Reksadana turun.

\section{Tanggungjawab Manajer Investasi terhadap Investor yang Dirugikan Dalam Reksadana Jika Terjadi Wanprestasi}

Setiap bentuk investasi tidak lepas dari risiko yang menyertainya. Lazimnya, semakin besar janji keuntungan, akan besar pula risikonya, tidak ada satupun bentuk investasi yang kebal dari risiko kerugian, termasuk Reksadana. Fluktuasi nila Reksadana akan sangat bergantung pada underlying asset-nya. Reksadana saham misalnya nilainya akan sangat bergantung dengan racikan portofolio saham yang dikelola oleh Manajer Investasi, walaupun indeks saham nilainya terus naik, tetapi kebetulan portofolio saham yang dikoleksi Manajer Investasi bukan termasuk golongan saham yang mendongkrak kenaikan indeks, maka kemungkinan nilai Reksadana justru menurun.

Meminimalisir risiko kerugian, sedapat mungkin invenstor dan pihak yang menjalankan investasi harus mengatur dan memahami hak dan kewajiban masing-masing, untuk investasi di instrumen Reksadana, calon investor harus membaca dan memahami prospetus yang dimiliki oleh perusahaan yang mengelola Reksadana. Prospektus biasanya dipaparkan pula mengenai risiko dalam berinvestasi di Reksadana. Isi prospektus harus mengacu pada Peraturan BAPEPAM-LK No. IX.C.6 Keputusan 
Ketua Bapepam N. Kep22/PM/2004 tentang Pedoman dan Isi Prospektus dalam Rangka Penawaran Umum Reksadana.

Masalah risiko Reksadana juga diatur pada huruf $k$ poin (1) Peraturan No. IX.C.6. Disebutkan, risiko yang diterima pemodal adalah kekurangannya nilai saham atau Unit Penyertaan disebabkan oleh kondisi makro ekonomi dan keamanan, wanprestasi dari pihak-pihak yang terkait dengan Reksadana seperti bank, perusahaan lain penerbit instrument pasar uang dan atau obligasi, dan perubahan nilai instrument pasar uang sebagai akibat pergerakan suku bunga dan kurs mata uang secara signifikan.

Pertanggungjawaban pihak yang dirugikan dalam bentuk penggantian kerugian. Penggantian kerugian dapat dituntut menurut undang-undang. Penggantian kerugian diatur pada KUHPerdata, Buku Ketiga bagian keempat mulai dari Pasal 1243-1252, yang dimaksudkan kerugian yang dapat dimintakan penggantian itu, tidak hanya yang berupa biaya-biaya yang sungguh-sungguh menimpa harta benda si berpiutang (schaden), tetapi juga yang berupa kehilangan keuntungan (interessen), yaitu keuntungan yang akan didapat seandainya si berhutang tidak lalai (winstderving). ${ }^{11}$

Untuk mengetahui bagaimana tanggungjawab Manajer Investasi, tentu harus dilihat pedoman tugas dari Manajer Investasi, yang jelas prospektus juga harus memuat tanggungjawab Manajer Investasi. Beberapa peraturan yang mengatur tanggungjawab Manajer Investasi selain Peraturan No. IX.C.6, juga peraturan No.IV.C.2 Keputusan Ketua Bapepam No.Kep24/PM/2004 tentang Nilai Pasar Wajar Dari Efek Dalam Portofolio Reksadana, dan

11 R Subekti. Pokok-Pokok Hukum Perdata, Intermasa, Jakarta, 2001, hlm. 148 peraturan No.IVV.B.1- Keputusan Ketua Bapepam No. Kep03/ PM/2004 tentang Pedoman Pengelolaan Reksadana Berbentuk Kontrak Investasi Kolektif.

Mementukan ada tidaknya unsur kesalahan atau kelalaian Manajer Investasi yang mengakibatkan kerugian investor tentu tidak biisa dilakukan secara sepihak. Pengawasan segala kegiatan yang berhubungan dengan penerbitan Reksadana masuk ke dalam domain Bapepam. Manajer Investasi yaitu wajib dengan itikad baik dan penuh tanggunggjawab menjalanka tugas sebaik-baik mungkin semata-mata untuk kepetingan Reksadana, dalam Pasal 27 ayat (2) disebutkan jika dalam hal Manajer Investasi tidak melaksanakan kewajibannya sebagaimana dimaksud dalam ayat (1), Manajer Investasi tersebut wajib bertanggungjawab atas segala kerugian yang timbul karena tindakannya.

Pertanggungjawaban yang dapat dimintakan kepada Manajer Investasi dapat berupa pertanggungjawaban secaa administratif, secara perdata, dan secara pidana, untuk pertanggungjawaban secara perdata, investor meminta pertanggungjawaban Manajer Investasi untuk mengganti segala kerugian yang diserita investor karena perbuatannyya yang wanprestasi atau perbuatan yang melawan hukum.

Selama Manajer Investasi melakukan pengurusan sesuai dengan perjanjian (kontrak investasi kolektif), peraturan perundang-undangan sampai dengan BAPEPAM-LK, dan fiduciary duty-nya maka Manajer Investasi tidak bertanggungjawab secara pribadi. Manajer Investasi dapat bertanggungjawab secara pribadi apabila terbukti melakukan pelanggaran terhadap segala ketentuan dalam perjanjian (kontrak investasi kolektif), peraturan perundang-undangan sampai dengan BAPEPAM-LK, dan fiduciary duty. 


\section{P E N U T U P}

Berdasarkan permasalahan yang dikaji mengenai Tanggungjawab Manajer Investasi Terhadap Investor Reksadana Jika Terjadi Wanprestasi, maka adapun kesimpulannya bahwa pertanggungjawaban Manajer Investasi terhadap investor yang dirugikan dalam Reksadana yaitu apabila terbukti melakukan perbuatan yang dilarang dalam perjanjian (kontrak invetasi kolektif), peraturan perundang-undangan sampai dengan peraturan BAPEPAM-LK sehingga menyebabkan kerugian pada investor, maka Manajer Investasi bertanggungjawab atas segala kerugian yang diderita investor akibat pelanggaran yang dilakukannya.

Dalam penyelesaian sengketa Reksadana penyertaan terbatas, Otoritas Jasa Keuangan turun lansung melakukan pemeriksaan dan penyidikan terhadap sengketa Reksadana penyertaan terbatas, apabila terbukti ada pelanggaran maka akan diproses secara hukum yang berlaku. Investor juga boleh memilih penyelesaian sengketa diluar pengadilan seperti meminta bantuan Badan Arbitrase Pasar Modal Indonesia ( BAPMI )
DAFTAR PUSTAKA

Bismar Nasution, Keterbukaan Dalam Pasar Modal. Fakultas Hukum Universitas Indonesia, Program Pascasarjana, Jakarta, 200.

Gunawan Widjaja dan Almira Prajna Ramaniya. Reksa Dana dan Peran Serta Tanggung Jawab Manajer Investasi dalam Pasar Modal. Seri Pengetahuan Pasar Modal. PrenadaMedia Group, Jakarta, 2006.

Hadisoeprapto, Hartono, Pokok-Pokok Hukum Perikatan Dan Hukum Jaminan, Liberty, Yogyakarta, 1996.

Munir Fuady, Pasar Modal Modern Cetakan ke-1, Bandung, Citra Aditya Bakti, 1996.

R Subekti. Pokok-Pokok Hukum Perdata, Intermasa, Jakarta, 2001.

www.nellafrnd.file.wordpress.com/ 